\title{
Neutral zone approach and external impression for rehabilitation of macroglossia: a case report
}

\author{
Hyeon Kang, Nu-Ri Seo, Sang-Won Park, Kwi-Dug Yun, Chan Park, Hyun-Pil Lim* \\ Department of Prosthodontics, School of Dentistry, Chonnam National University, Gwangju, Republic of Korea
}

Macroglossia is an obstacle in regard to general prosthodontic restoration. Not only is it difficult to obtain support and stability from dentures manufactured from normal protocol, obtaining efficacy from basic mastication is also difficult. In such cases, realizing harmony between the occlusion and surrounding muscle structures may be important with regard to manufacture of stable full dentures, and it is necessary to form the appropriate polished surface for this case. The neutral zone is defined as the potential area resulting from the neuromuscular function that results in equilibrium between the outward force exerted by the tongue and the inward force exerted by the lips and cheeks. The artificial teeth of the full denture lies in this area, and if the polished zone follows the anatomic form of the dynamic muscles, the movement of the muscles simply acts as an element of stabilizing the dentures improving the esthetics through facial support. (J Dent Rehabil Appl Sci 2018;34(3):218-24)

Key words: macroglossia; neutral zone; external impression

\begin{abstract}
서론
혀는 구강저에 부착된 근육기관으로 의치 제작 시 중 요하게 고려되어야 할 요소이다. 특히, 혀의 운동 및 공 간을 고려치 않은 의치의 제작은 의치의 유지 및 안정성 을 크게 저하시키게 된다. ${ }^{1}$ 따라서 환자가 거대설을 가진 경우에는, 일반적 보철 수복을 진행하는 데에 큰 어려움 이 따르기 마련이다. 거대설은 턱의 크기에 대한 혀의 상 대적 비대를 나타내는 상태를 말하며, 치열의 기형 및 저 작, 발음, 기도 유지의 문제 등을 유발할 수 있는 것으로 알려져 있다. ${ }^{2,3}$ 이와같은 환자에서 치조골의 해부학적인 지표만을 가지고 의치의 치아 배열을 시행하고 통상적 인 연마면을 형성할 경우, 제작된 의치로서 적절한 유지 와 안정을 얻기 어려울 수 있고 이와 더불어 저작의 효율 또한 감소될 수 있다. 이러한 경우 안정적인 의치를 제작
\end{abstract}

*Correspondence to: Hyun-Pil Lim

Associate Professor, Department of Prosthodontics, School of Dentistry, Chonnam National University, 33 Yongbong-ro, Buk-gu, Gwangju, 61186, Republic of Korea

Tel: +82-62-530-5638, Fax: +82-62-530-5639, E-mail: mcnihil@chonnam.ac.kr Received: May 9, 2018/Last Revision: June 29, 2018/Accepted: July 23, 2018
하기 위해서는 의치의 교합뿐 아니라 주변 근육 조직과 의 조화가 중요한 요소가 될 수 있고, 이를 위해서 연마면 을 적절히 형성하는 것이 필요하다. 중립대(neutral zone) 는 혀가 밖으로 미는 힘과 볼과 입술이 안으로 미는 힘이 평형을 이루는 근신경계 기능에 의한 잠재적 영역으로 정 의되며, 총의치의 인공치가 이 영역에 위치되고, 연마면 형태가 동적인 근육의 해부학적 형태를 따른다면 근육 의 움직임은 의치를 안정시키는 요소로 작용할 뿐 아니 라 안면 지지를 통하여 심미성 또한 향상될 수 있다는 장 점이 있다. ${ }^{4}$ 중립대 개념에 중점을 두어 제작한 가철성 의 치는 구강 주위 근육과의 적절한 조화를 나타내며 효율 적인 의치 기능을 하는 장점을 가진다. 혀 공간을 적절히 허용하는 의치상 구치부의 위치와 대구치 부위의 음식물 침착 감소, 향상된 유지 및 안정 그리고 구순지지와 관련 한 안모 심미성 획득이 그것이다. ${ }^{5}$

Copyright@ 2018 The Korean Academy of Stomatognathic Function and Occlusion. (c) It is identical to Creative Commons Non-Commercial License. 
본 증례의 환자는 위아래 틀니를 새로 만들고 싶다는 주소로 내원한 완전 무치악 환자로, 지속적인 치조골 소 실 및 장기간 무치악 상태로 인한 혀의 거대화 등 의치의 안정 및 유지 기능이 상실된 상태였다. 하악의치의 안정 및 유지를 향상시키기 위해 중립대 개념을 적용하여 총의 치 수복한 증례이다.

\section{증례보고}

본 증례의 환자는 60 세의 남성 환자로 위아래 틀니를 만들고 싶다는 주소로 내원하였고, 기존에 의치는 2년 전 에 분실한 뒤, 사용하고 있지 않았다. 전신병력으로는 뇌 병변으로 인한 지체장애가 있었고, 항우울제를 약 1년 여 간 복용 중이었다. 진단을 위해 구내 임상 검사 및 파노라 마 방사선 사진 촬영 및 구내, 구외 사진 촬영, 그리고 진 단 모형을 위한 인상 채득을 시행하였다(Fig. 1, 2). 환자 는 수술에 대한 부담감과 경제적인 문제로, 임플란트를 이용한 고정성 보철물 제작은 원하지 않았고, 상하악 총 의치 제작을 원하였다.

우선 기존 사용하는 의치가 분실된 상태였고, 2 년간 의 치 사용을 하지 않았기 때문에, 임시의치를 제작하였다 (Fig. 3). 하지만, 임시의치 장착 후, 관찰 기간 동안 큰 혀의
위치와 움직임으로 인해 하악의치의 유지 및 안정성에 문 제가 발생하였고, 환자 역시 의치 사용을 어려워 하였다.

임시의치 장착하여 경과관찰 후, 새로운 의치를 제작 하기 위하여 알지네이트(Cavex Impressional, CAVEX, Haarlem, Netherland)를 이용하여 상하악 무치악의 인 상을 채득하여 진단 모형 제작하였으며 진단 모형 상 에서 개인트레이를 제작하였다. 환자의 다음 내원시에 는 modeling compound (Modeling Compound, Kerr Corp., Orange, USA)로 변연 형성 후, Exadenture (Exadenture, GC Corp., Tokyo, Japan)를 사용하여 상하악 기능인상 채득하였고, 이를 이용하여 최종 모형 제작하 였다(Fig. 4). 환자의 악간관계채득을 위해, 최종 모형 상

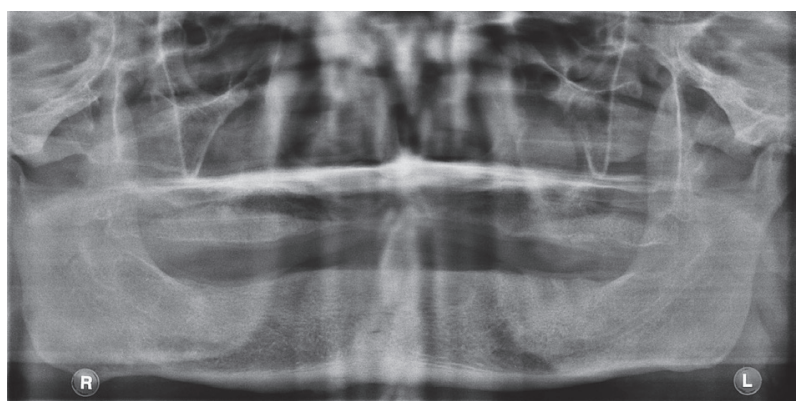

Fig. 1. Initial panoramic radiograph.
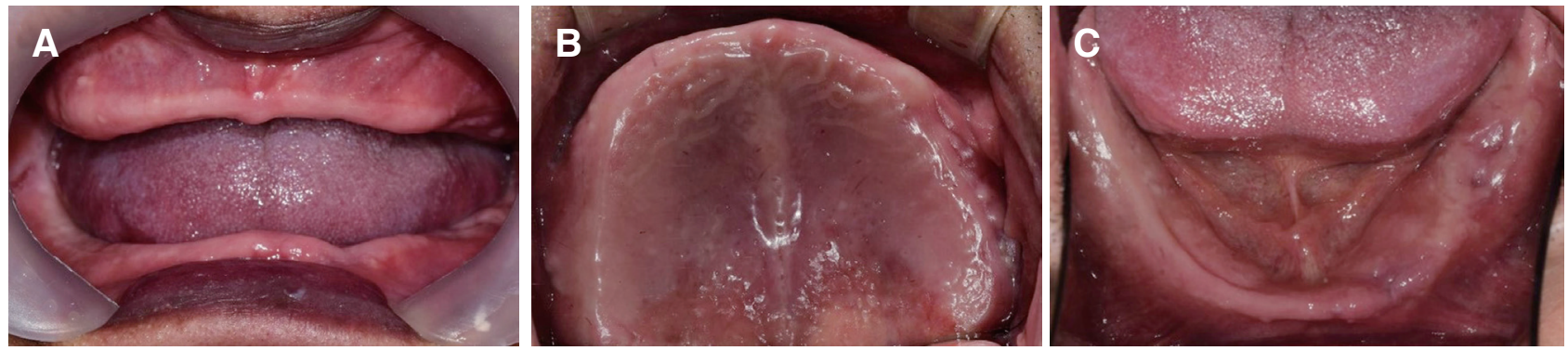

Fig. 2. Initial intraoral photographs. (A) Frontal view, (B) Occlusal view of maxilla, (C) Occlusal view of mandible.
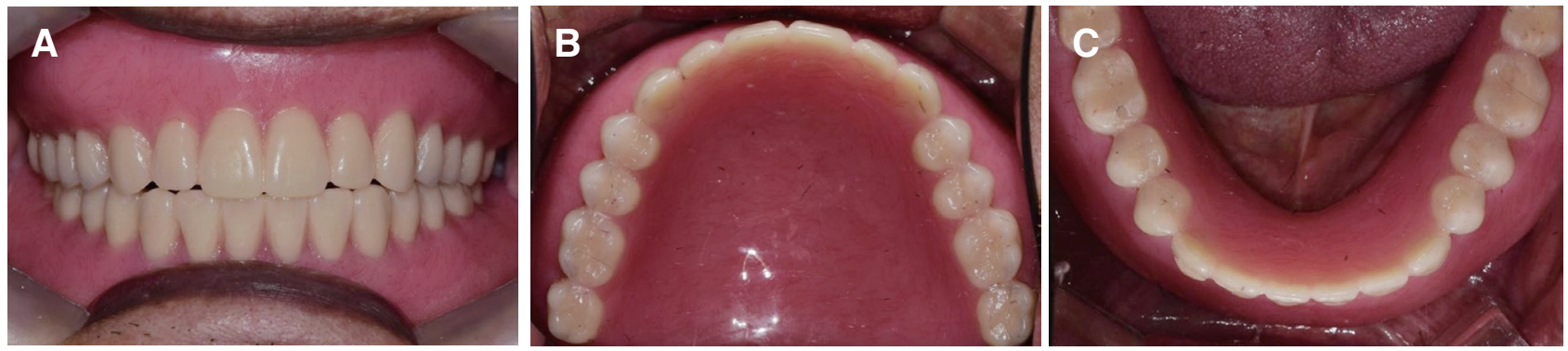

Fig. 3. Provisional denture. (A) Frontal view, (B) Occlusal view of maxilla, (C) Occlusal view of mandible. 

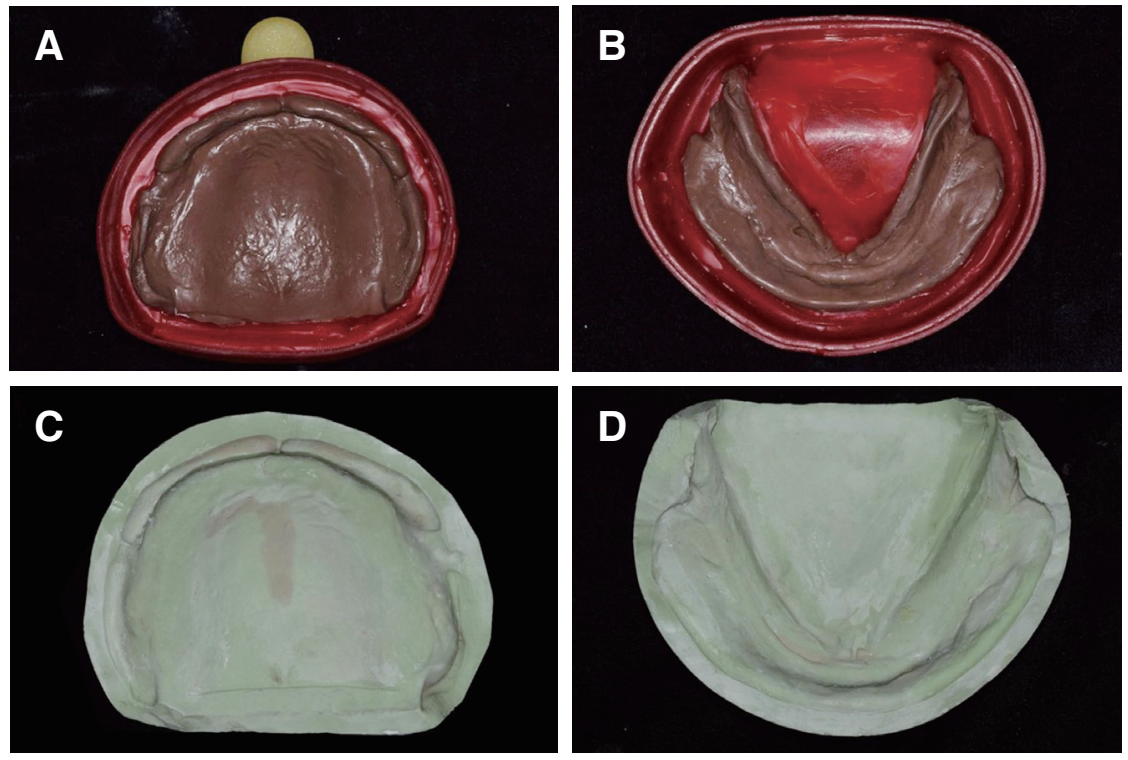

Fig. 4. Final impression (A, B) and Master cast (C, D).
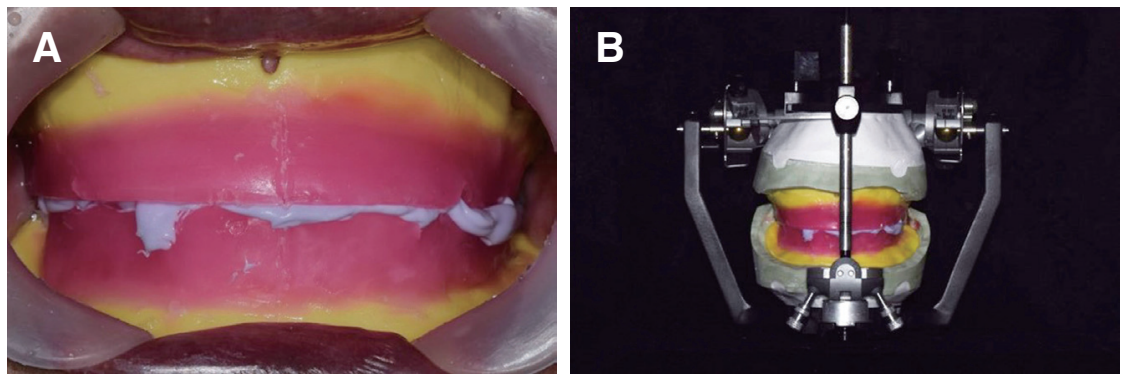

Fig. 5. Vertical dimension and centric recording (A), Mounting of master casts (B).
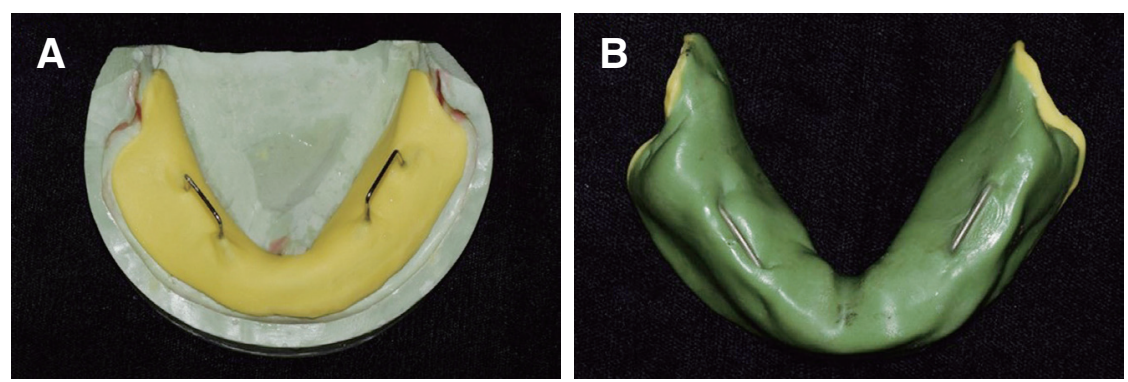

Fig. 6. Lower acrylic resin base with retentive loops (A), compound rim (B).

에 기초상과 교합제를 제작하여 환자 내원 시, 안궁이 전과 교합고경, 중심위 채득을 시행하였다(Fig. 5). 중립 대 재현을 위한 compound rim 제작은 최종 모형상에 서 acrylic resin으로 기초상을 제작하고, 그와 동시에 1.0 $\mathrm{mm}$ wire를 이용하여 retentive loop를 형성하여 골격 형 성 하였다(Fig. 6). 이후, 환자 내원 시 진료시간 단축 및 중립대 인기과정 중에 오차를 줄이기 위해, 기존에 채득
한 교합고경에 맞도록 compound rim을 형성하였다. 다 음 환자 내원시, 준비한 기초상에 modeling compound 를 조금씩 추가 및 제거하면서, compound rim을 수정하 였고, 수정 과정에서 환자로 하여금 입술을 핝거나 혀를 내미는 동작, 연하 운동, '이(E)'와 ‘오 $(\mathrm{O})$ ' 발음 등의 기 능 운동을 시행하여 혀와 볼 및 입술의 근육운동이 반영 되게 하였다(Fig. 6). 수정된 compound rim은 부가중합 
형 실리콘 인상재 putty (Extrude XP putty, Kerr Corp., Orange, USA)를 이용하여 compound rim을 복제하여 index를 제작 하였고, 이를 기준으로 치아 배열 시행함 으로써, 환자의 중립대 내에 인공치아 배열되도록 하였 다(Fig. 7). 인공치아를 배열할 때, 하악 치조제 관계가 정 상 교합 범위에 포함되는 것으로 판단되어, 해부학적 치 아(Endura, Shofu Inc., Kyoto, Japan)를 이용하여 양측 성 균형 교합(bilateral balanced occlusion)으로 치아 배 열을 시행하였다. 치아 배열이 완료된 납의치는 환자 내 원 시 시적하여 안모 평가 및 수직고경, 교합 등을 확인 하였고, 연마면 형성 위해 external impression 시행 하였 다(Fig. 8). 상하악 납의치 상의 치은 부위 왁스를 제거 하 고, Coe-comfort (Coe-comfort, GC America, Chicago, $\mathrm{USA}$ )를 적용한 후, 구강 내에서 환자로 하여금 기능운 동을 시행하도록 하였다. 이후, 의치의 온성을 시행한 후
기공실 재부착 과정을 통하여 교합 조정을 시행 하였고, 의치의 마무리와 연마를 통해 최종 의치를 제작 하였다. 환자에게 최종 의치 시적 후, 교합관계 확인하였고, 다시 악간 관계 채득하여 진료실 재부착을 통하여 선택 삭제 를 시행한 후 의치를 장착하였다(Fig. 9, 10). 최종의치 제 작 후, 기존 임시 의치와 비교 분석 위해 3Shape viewer (3Shape viewer, 3Shape, Copenhagen, Denmark) 프로 그램을 사용하여, 단면 분석 시행하였다(Fig. 11). 임시 의 치를 기준으로 최종 의치의 연마면 관찰 시, 환자의 거대 설과 볼의 상호작용을 고려한 형태를 띄었으며, 중립대 개념의 영향으로 구치부 치아 배열 위치의 경우 조금 더 협측 위치 된 것을 확인 할 수 있었다. 중립대 개념으로 제작된 최종의치의 안정되고 향상된 유지력에 환자 역시 기능적, 심미적인 면에서 만족하였다.


Fig. 7. Artificial tooth arrangement according to the silicone putty index (A, B).
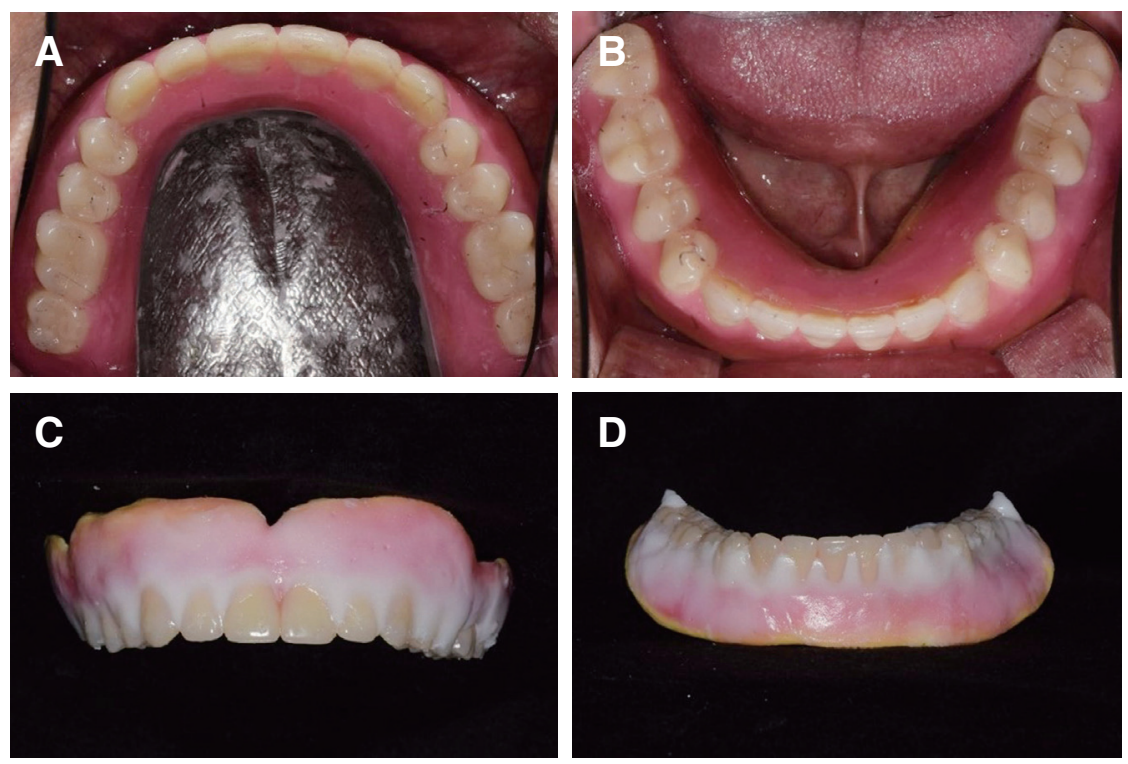

Fig. 8. Wax denture (A, B), External impression on upper wax- denture using Coe-soft (C) and External impression on lower wax- denture using Coe-soft (D). 

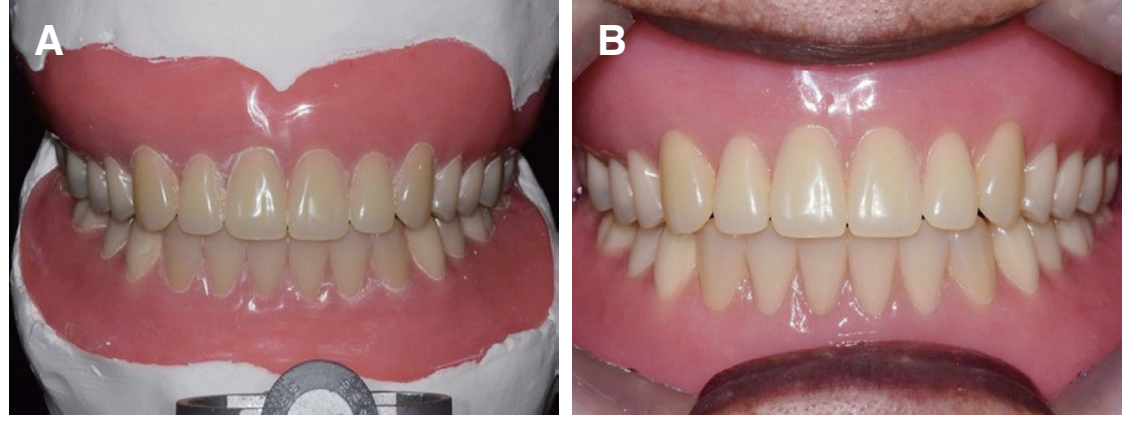

Fig. 9. Clinical remounding (A), Denfinitive denture delivery (B).
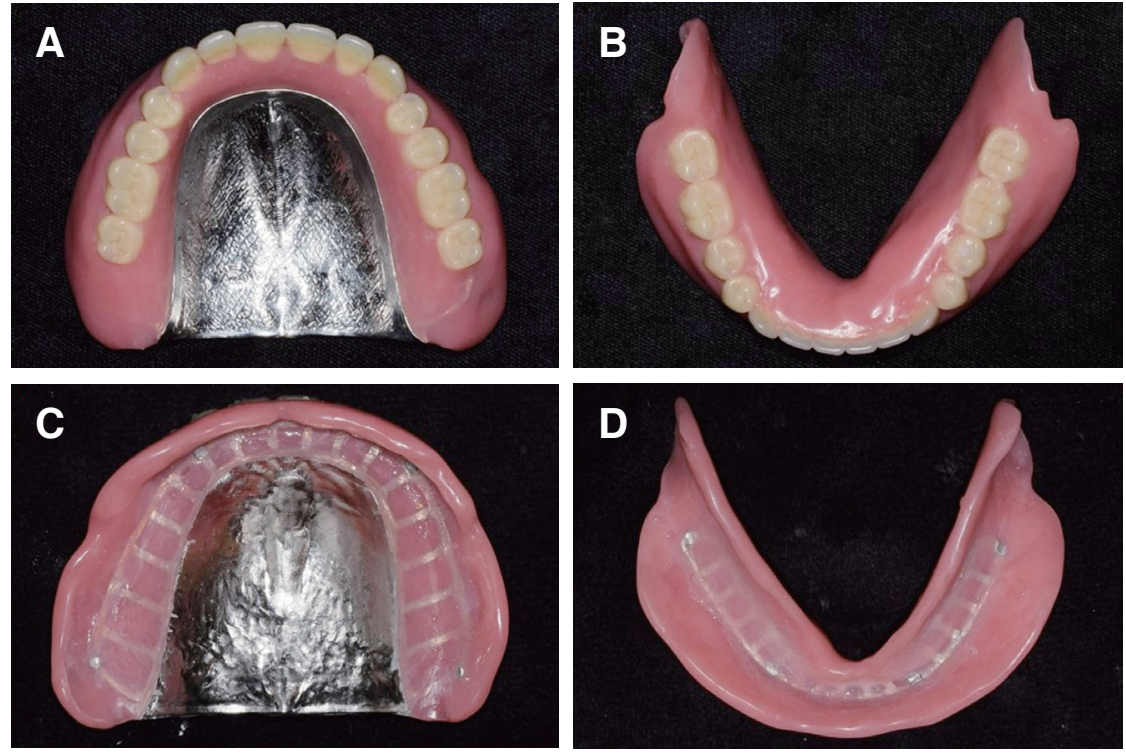

Fig. 10. Polished surface (A, B), tissue surface (C, D) of new denture.

A

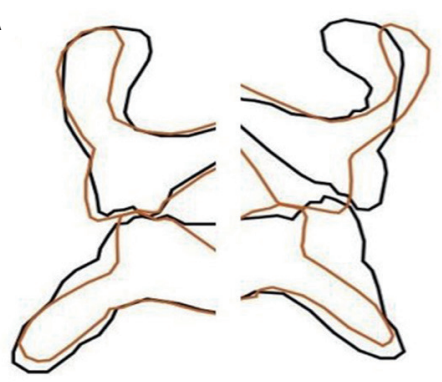

B



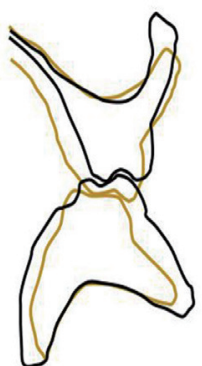

Fig. 11. Comparison of Cross sectional view of new denture (black line) and provisional denture (brown line) at premolar area $(\mathrm{A})$ and molar area $(\mathrm{B})$ by 3 Shape viewer ${ }^{\circledR}$. 


\section{고찰}

본 증례를 통해, 거대설을 가지며 지속적인 치조골 소 실을 가진 상하악 완전 무치악 환자에서 중립대 개념 을 적용한 총의치를 제작 함으로써 향상된 유지와 안정 을 가진 의치를 환자에게 전달할 수 있었고, 심미적으로 도 개선된 결과를 얻을 수 있었다. 총의치의 제작 시, 치 아 위치 와 연마면의 형태 및 윤곽은 유지 및 안정에 매우 중요한 요소 이다. 특히, 거대설을 가지거나, 심한 치조골 흡수 등의 총의치 제작 시에 난관이 예상되는 경우에는 조금의 유지 및 안정 확보가 중요하다.

중립대는 환자의 혀 근육의 힘과 볼 및 입술 주위 근육 의 힘이 평형을 이루는 근신경계의 잠재적 영역으로, 이 는 오랜시간 환자의 습관과 근육 활성도에 따라 형성된 다. ${ }^{2}$ 총의치 제작시 치아배열을 중립대 내에 설정하고, 연 마면 형성시 중립대 개념의 적용은 의치 제작의 기준을 상하악 무치악 치조제 뿐만 아니라, 환자의 온전한 구강 환경 및 주위 환경의 조화 내에 두는 것이 될 것이다. ${ }^{6-8}$ 이 러한 중립대 개념 적용 의치 제작시, 환자의 기능 운동을 통하여 중립대를 인기하고 연마면 형성이 되기 때문에 기 존의 통법의 총의치 제작시 보다 환자의 적극적인 협조 도가 중요하다. 따라서, 의치 제작시기에 앞서, 충분한 설 명과 치료 계획 전달이 필요하며, 환자의 교육 및 훈련 과 정이 필요할 수 있다.

이러한 환자 교육은 최종 의치 전달 후에도 지속되어 야 하며, 중립대를 적용한 의치의 장기적 재내원시 환자 의 유지 및 안정에 대한 만족도 평가와 의치 평가가 필요 할 것으로 보인다.

\section{결론}

본 증례는 거대설을 가진 환자에서 총의치 제작시 중 립대 개념을 적용한 증례로, 완성된 상하악 총의치에서 여러 기능 운동 및 저작 운동시 향상된 안정과 유지를 보 였으며 환자도 기능적, 심미적으로 만족하였기에 이를 보고하는 바이다.

\section{ORCID}

Hyeon Kang https://orcid.org/0000-0003-3999-2871

Nu-Ri Seo https://orcid.org/0000-0003-0291-6410

Hong-So Yang https://orcid.org/0000-0002-9138-4817
Sang-Won Park https://orcid.org/0000-0002-9376-9104

Kwi-Dug Yun https://orcid.org/0000-0002-2965-3967

Chan Park https://orcid.org/0000-0001-5729-5127

Hyun-Pil Lim https://orcid.org/0000-0001-5586-1404

\section{References}

1. Bhupinder K, Gaurav G, Navreet S, Sarabjeet S, Gurpreet K, Tina G. Tongue: the most disturbing element in mandibular denture - how to handle it? Ann Dent Res 2012;2:44-51.

2. Wolford LM, Cottrell DA. Diagnosis of macroglossia and indications for reductive glossectomy. Am J Orthod Dentofacial Orthop 1996;110:170-7.

3. Rogers RS 3rd, Bruce AJ. The tongue in clinical diagnosis. J Eur Acad Dermatol Venereol 2004;18: 254-9.

4. Beresin VE, Schiesser FJ. The neutral zone in complete dentures. 1976. J Prosthet Dent 2006;95:93100.

5. Gahan MJ, Walmsley AD. The neutral zone impression revisited. Br Dent J 2005;198:269-72.

6. Schiesser FJ. The neutral zone and polished surfaces in complete dentures. J Prosthet Dent 1964;14: 854-65.

7. Cagna DR, Massad JJ, Schiesser FJ. The neutral zone revisited: from historical concepts to modern application. J Prosthet Dent 2009;101:405-12.

8. Rehmann P, Zenginel M, Wostmann B. Alternative procedure to improve the stability of mandibular complete dentures: a modified neutral zone technique. Int J Prosthodont 2012;25:506-8. 


\section{거대설을 가진 환자에서 중립대 개념과 연마면 인상을 이용한 총의치 수복 증례}

\section{강현, 서누리, 박상원, 윤귀덕, 박찬, 임현필*}

전남대학교 치의학전문대학원 보철학교실

거대설은 일반적인 보철 수복을 진행하는 데에 장애물이 되는 요소 중의 하나이다. 이러한 환자에서 통상적인 방법으로 제작된 의치는 유지와 안정을 얻기 어려울 뿐 만 아니라, 기본적인 저작의 효율 또한 얻기 힘들 것이다. 이러한 경우 안정 적인 의치를 제작하기 위해서는 의치의 교합뿐 아니라 주변 근육 조직과의 조화가 중요한 요소가 될 수 있고, 이를 위해 서 연마면을 적절히 형성하는 것이 필요하다. 중립대(neutral zone)는 혀가 밖으로 미는 힘과 볼과 입술이 안으로 미는 힘 이 평형을 이루는 근신경계 기능에 의한 잠재적 영역으로 정의되며, 총의치의 인공치가 이 영역에 위치되고, 연마면 형태 가 동적인 근육의 해부학적 형태를 따른다면 근육의 움직임은 의치를 안정시키는 요소로 작용할 뿐 아니라 안면 지지를 통하여 심미성 또한 향상될 수 있다는 장점이 있다.

(구강회복응용과학지 2018;34(3):218-24)

주요어: 거대설; 중립대; 연마면 인상 